\title{
Analysis of State Court Of Batang Decision Number: 4 / Pid.Sus / 2018 / Pn Btg on Felony Obscenity Crime Based On Islamic Criminal Law
}

\author{
Bagus Langgeng Prasetiyo ${ }^{1}$, Gunarto $^{2}$ and Munsharif Abdul Chalim ${ }^{3}$
}

\begin{abstract}
In the case of sexual crimes where the child victim, the victim could be the driving factors behind crime. For example, we say today is increasingly widespread promiscuity, children have been left free in terms of promiscuity and lack of supervision of their parents, the They were released along with others, go anywhere. So, with their innocence, they could be trapped in one association and exploited by the parties or adults who are not responsible. In such circumstances, the public, law enforcement officers and even a State shall be estimated on the protection and supervision of children, especially where children as crime victims of sexual crimes indeed very concerned and could undermine future portion of the prospective successor to the nation.

Therefore, the authors are interested in writing this thesis titled "Analysis of State Court of Batang Decision No. 4 / Pid.Sus / 2018 / PN Btg About felony obscenity According to Islamic Criminal Law".

In this study the authors use this type of research descriptive with normative juridical approach. Data were collected by literature study, observation and interviews. Methods of qualitative analysis.

At the end of the study authors conclude that the author found consideration of the judge in the imposition of a criminal judgment against the defendant in Decision No. 4 / Pid.Sus / 2018 / PN.Btg compliance, that have noticed the elements of the criminal case, after seeing the Islamic law according to the author was still lacking and not worth the Hadd punishment. So the result rather than the judge's decision according to the author can not be unfair to the accused and the victim.

Keywords: Juridical Studies; Felony Obscenity Crime; Islamic Criminal Law
\end{abstract}

\section{Introduction}

Indonesia is a country of law as stipulated in the 1945 Constitution, particularly Article 1 (3), this means that all aspects of life in this country governed by the rule of law. ${ }^{4}$ In an effort to realize the enforcement of the rule of law in Indonesia, the necessary laws in this legislation that serves as a regulator of the actions of society as well as a means of forced to the community. Children as one subject of law in this country should also be subject to and comply with applicable laws.

Islamic law prescribed by Allah with the primary objective is to realize and protect the benefit of mankind, whether the benefit of individuals and communities. The benefit to be realized in the Islamic law concerning all aspects of human interest. Aspects of

\footnotetext{
${ }^{1}$ Student of Master of Law, Universitas Islam Sultan Agung Semarang and Polres Batang, Email : baguslanggengp7@gmail.com

${ }^{2}$ Lecturer of Master of Law, Faculty of Law, UNISSULA, Semarang

${ }^{3}$ Lecturer of Master of Law, Faculty of Law, UNISSULA, Semarang

${ }^{4}$ Explanation 1945 in Article 1 (3) of the State of Law
} 
human interests, according to the scholars can clasification into three aspects, namely Dharruriyat (primary), Hajjiyat (secondary) and Tahsiniyyat (social stability). ${ }^{5}$

Based on the terminology in the Indonesian General Dictionary, "harassment", the origin of the word sycophant ${ }^{6}$ means persuader / likes praise, "sexual" ${ }^{7}$ with regard to sex (male-female) with respect to the case mix between male and female, "child" second derivative; humans are still small. ${ }^{8}$ Child sexual abuse is a general term describing criminal and civil where adults engaging in sexual activities with children or exploitation of children for the purpose of sexual gratification.

In such circumstances, the public, law enforcement officers and even a State shall be estimated on the protection and supervision of children, especially where children as crime victims of sexual crimes indeed very concerned and could undermine future portion of the prospective successor to the nation.

Based on the description that has been presented above, which is the case in this study is how the jurisprudence Jinayah review and consideration of the judge in sentencing for perpetrators of felony obscenity in the decision number: 4/ Pid.Sus / 2018 / PN Btg?

\section{Research Methods}

The approach used in this research is normative juridical approach. Normative juridical approach is research which refers to the legal norms contained in legislation and court rulings and legal norms that exist in society. ${ }^{9}$ Thus, this study is a qualitative research, the data collected in the form of text, not numbers. ${ }^{10}$ The results of the study after a through analysis then presented with a description of using the language of prose in the form of research reports Journal. ${ }^{11}$ The analysis process is an attempt to find answers to questions about the formulas and lessons or things that we have gained in research projects. ${ }^{12}$ This study used data analysis methods such as qualitative analysis. A qualitative approach is actually a research procedure that produces descriptive data, which is what was stated by the respondent in writing and oral, and real behavior. Who researched and studied is the whole object of investigation. ${ }^{13}$

\section{Results And Discussion}

\subsection{Consideration Judge In Penalty Dropped Against Perpetrators of Felony Obscenity Crime In Decision No. 4 / Pid.Sus / 2018 / PN Btg.}

R.Soesilo is obscene according to any acts that violate morality (propriety) or

\footnotetext{
${ }^{5}$ Said Agil Husin Al-Munawar, Jakarta, Hukum Islam, Penamadani, 2005, p.19

${ }^{6}$ W.J.S. Poerwadarminta, Kamus Umum Bahasa Indonesia, Third Edition, Balai Pustaka, Jakarta, in 2005, p.859

${ }^{7}$ lbid, p.1055

8 Ibid, p.35

${ }^{9}$ Zainudin Ali, Metode Penelitian Hukum, Sinar grafika, Jakarta, Ed. $4^{\text {th }} .2013$, p.105

${ }^{10}$ Sudarwan Danim. Menjadi Peneliti Kualitatif, CV. Pusaka Setia, Bandung, Ed.1. 2002. p. 51

${ }^{11}$ Ibid., p. 15

${ }^{12}$ Marzuki. 2000. Metodologi Riset, Yogyakarta, Faculty of Economics Publisher Agency (BPFE), p.87.

${ }^{13}$ Soerjono Soekanto, op. cit.p. 32.
} 
abominable deeds, all in the neighborhood of lust sex, for example: kissing, groping member genitals, breasts, and so on. ${ }^{14}$

Also according to Bemmellen, prohibition of obscene acts and punishment of perpetrators of abuse is shown to maintain certain relationships, or certain powers, such as the biological parent, stepparent, guardian, employers and people who become caregivers, educators, or guard children children entrusted and its responsibility. ${ }^{15}$

Of abuse in the form of violence and threats of violence to sexual intercourse with children regulated in Act No. 35 of 2014 amendments to the Act No. 23 of 2002 on Child Protection on Article 81 paragraph (1) and (2) which states:

- Any person intentionally committing violence or threats of violence to force children to do intercourse with her or with another person, shall be punished with imprisonment for a period of 15 (fifteen) years and 3 (three) years and a fine of $\mathrm{Rp} 300,000,000.00$ ( three hundred million rupiah) and least Rp60,000,000.00 (sixty million rupiahs).

- Criminal provisions referred to in paragraph (1) shall also apply to any person who deliberately ruse, a series of lies, or persuade a child had intercourse with her or with other people.

Consideration of a judge is one aspect that is very important for realizing the value of a judge's decision that include the fair (ex aequo et bono) and contain legal certainty, in order that there are also benefits for the parties concerned so judges must be addressed thoroughly, well, and carefully. If the judges are not careful, kind, and meticulously, the decision comes from the consideration of the judge which will be canceled by High Court / Supreme Court. ${ }^{16}$

- Juridical considerations; Lilik Mulyadi ${ }^{17}$ argued that "the essence of juridical considerations judge is proving the elements of an offense, whether the actions of the defendant conform and adapt to the offense indicted by the public prosecutor verdict". In the practice court at the judge's decision before juridical considerations is proved, the judge will first attract the facts in the trial were raised and the cumulative conclusion of witness testimony, information from the defendant and evidence.

- sociological considerations; In Act No. 48 of 2009 Article 5 (1) states that a judge shall explore, and understand the legal values and sense of justice in society. This provision is that the judge's decision in accordance with the law and a sense of justice. So, judge a formulator and diggers legal values that live among the community. Therefore, he must plunge amongst the people to know, feel and being able to explore the legal sense and sense of justice in society.

\footnotetext{
14 R. Soesilo, 1996, Kitab Undang-Undang Hukum Pidana (KUHP) serta Komentar-komentarnya Lengkap Pasal Demi Pasal, Politea, Bogor, p. 212.

${ }^{15}$ Neng Djubaidah, Perzinaan, Ed. 1; Jakarta: Kencana Prenada Group, 2010, p. 75

${ }^{16}$ Mukti Aro. 2004. Praktek Perkara Perdata pada Pengadilan Agama. Ed V., Yogyakarta. Pustaka Pelajar, p.140.

17 Lilik Mulyadi, 2007, Putusan Hakim dalam Hukum Acara Pidana: Teori, Praktik, Teknik Penyusunan, dan Permasalahannya, Citra Aditya Bakti, Bandung, p. 193.
} 
Then Traffic policy implementation by Resort Police of Batang Sat implemented in various forms of activities in accordance with the Guidelines Chief of Police No. Pol.: juklak/ 05/2003 Date May 29, 2003 On Implementation Guidelines for Public Education of Traffic (Dikmas Lantas) that has been planned and organized in the National Road Safety "LLAJ" Program have been executed better. Activities in the program that have been prepared are implemented according to the following targets:

Based on Decision Number 4/Pid.Sus/2018/ PN.Btg defendant Musholin As Toyib Bin Darsono insists that the defendant is guilty of a criminal act "violence to force children to do obscene acts " in accordance with the Article $82 \mathrm{E}$ Jo Article 76 of Act No. 35 of 2014 on the Amendment of Act No. 23 of 2002 on Child Protection as follows: Any person who violates the provisions referred to in Article 76E (the contents of Section $76 E$ namely: "any person prohibited from engaging in violence or threats of violence, force, deceit, conducted a series of lies, and persuade a child to do or let do obscene acts") shall be with a term of imprisonment of five (5) years and a maximum of 15 (fifteen) years and a maximum fine of Rp. 5,000,000,000.00 (five billion rupiah).

In the case of a criminal act referred to in paragraph (1) shall be done by a parent, guardian, babysitter, teachers, or staff, then the sentence plus $1 / 3$ (one third) of the criminal sanction as referred to in paragraph (1).

The author argues that the judge's consideration in the imposition of a criminal judgment against the defendant in Decision No. 4 / Pid.Sus / 2018 / PN.Btg compliance, that have noticed the elements of the criminal case, the State Court Judge Rod Assembly believes that the defendant Musholin As Toyib Bin Darsono proven legally and convincingly guilty of committing violence or threats of violence, force, deceit, conducted a series of lies, or persuade the Son, then that person may be liable to Article 82 Jo Section 76 E of Act No. 35 of 2014 on the Amendment Act No. 23 of 2002 on Child Protection impose imprisonment for five (5) years, and a criminal fine of Rp. $60,000,000,-$.

\subsection{Fiqh Jinayah Overview To Judge Decision Against Perpetrators of Felony Obscenity Crime In Decision No. 4 / Pid.Sus / 2018 / PN Btg.}

Obscene acts that until the sexual intercourse can be considered to act of adultery. Adultery is a man to fuck a woman through Qubul (vagina or genitalia), who is not his wife, without going through Syubhatan Nikah or doubtful marriage. The legal basis for the prohibition of adultery contained in the Word of God:

Meaning: "Women who commit adultery and men who commit adultery, then whip each one of them a hundred flagellation, nor compassion for both preventing you to (run) the religion of Allah, if ye believe in Allah and the Last Day, and let (implementation) their punishment be witnessed by a group of people who believe. Men who commit adultery but do not marry the adulterous woman, or a woman who idolaters; and the woman taken in adultery did not marry, but by men who commit adultery or male idolaters, and thus it is forbidden on who are believers, "(An-Nur: 23). ${ }^{18}$

\footnotetext{
${ }^{18}$ Ministry of Religious Affairs, AL-Qur'an dan Terjemahan, PT Syaamil Cipta Media, p.285
} 
In Islamic law, molestation that has not reached sexual contact is inserted into the category of acts near adultery (Mukadimah Zina) is obscene acts that could cause adultery.

In the Qur'an, there is a prohibition act approach adultery in Surah Al-Israa' verse 32: Meaning: "And do not approach adultery; in fact adultery is a heinous act. And an evil way,"(Al-Israa': 32) $)^{19}$

The reasons for the prohibition of acts near adultery, according to the Mufassirin of Tashih Team of Mushaf Al-Qur'an of Ministry of Religious Affairs of the Republic of Indonesia, is due to fornication was a heinous act that can result in damage to, among other things:

- Fornication was mixing descent, which resulted in someone be hesitant towards their children, whether the child is born as a legitimate descendant or child of adultery. Alleged husband to wife of adultery with another man, can create difficulties in terms of the legal position of the child in question. This can result in delays in offspring survival and destroy the social order.

- Fornication cause instability and anxiety among members of the community, due to not maintaining the honor. As a result of the occurrence of fornication much lead to a criminal case of soul murder or in society.

- Fornication can ruin the tranquility of life settle down. A woman or a man who has committed adultery stigmatization or stain families in the local community, giving rise to disharmony and there is no peace and there is no tranquility in relation householder's life, especially if the adultery committed by the husband or wife is concerned.

- Fornication can destroy domestic life or family concerned. That's because the husband or wife adultery means he has tarnished the household or family, so it will be difficult for the inevitable from broken homes. ${ }^{20}$

Approaching criminal offense of fornication is a criminal offense $T a^{\prime} z i r$. Definition $T a^{\prime} z i r$ of criminal offenses according Encyclopedia of Islamic Criminal Law, are criminal acts that form and amount of the penalty is notcan be determined by the laws of Personality. Ta'zir criminal acts of all crime that the punishment in the form of $T a^{\prime} z i{ }^{21}$ The defendant has been convicted of felony obscenity to children, judging from the Islamic criminal law defendant is adultery is included in Jarimah Hudud where a legal provision that has been established by God.

In determining that a child, jurists refer to age in order to apply to everyone, by basing on the circumstances prevalent in small children. This limit is needed to avoid legal confusion and to make it easier for a judge to examine whether existing thinking ability in a person a child or not because the child's age can be determined easily. Mumayis child is considered yet if he was not yet up to seven years even though there is a child under seven years earlier to be able to distinguish good and bad of the other children his age. $^{22}$

\footnotetext{
19 Ibid.

${ }^{20}$ Neng Dzubaedah, 2010, Perzinaan, Jakarta: Kencana, p. 73-75

${ }^{21}$ Ibid, p. 287

${ }^{22}$ Ahsin Sakho Muhammad, et. al. Ensiklopedi Hukum Pidana Islam II, Bogor ; PT. Kharisma IImu, t.th 2007, p, 256
} 
State Court of Batang in a verdict on the accused Musholin As Toyib Bin Darsono has considered the things contained in the defendants themselves and not according to what is in the Shari'ah. Where implementation of Hadd punishment carried out in public with as much as a hundred times whipscan deter the defendant, because of the pain and tremendous mental pressure. Therefore, according to the author of a sentence of imprisonment for five (5) years, and a criminal fine of Rp. 60,000,000, (sixty million rupiahs) with the provision that if the penalty is not paid then it should be replaced with imprisonment for 3 (three) months, after seeing the Islamic law according to the author it is still lacking and is not commensurate with the Hadd punishment.

\section{Closing}

From the research and data of Analysis Of State Court Of Batang Decision Number: 4/Pid.Sus/2018/Pn Btg On Felony Obscenity Crime Based On Islamic Criminal Law who authors conclude affirmation of the need for measures against severe sanctions to combat felony obscenity to children, Therefore all parties, both government and society actively participate in efforts to prevent felony obscenity against children.

For the parties authorized to perform tasks in handling the trial judge or rape must understand and master the material and its problems so as to provide a deterrent effect as well as justice the perpetrators or the victims in this case are still under age.

\section{References}

[1] Ahsin Sakho Muhammad, et. al. Ensiklopedi Hukum Pidana Islam II, Bogor ; PT. Kharisma IImu, t.th 2007.

[2] Andi Sofyan dan Nur Azisa, 2016, Hukum Pidana, Makassar: Pustaka Pena Press.

[3] Departemen Agama RI, Al-Qur'an dan Terjemahan, PT Syaamil Cipta Media.

[4] Herabudin, 2016, Studi Kebijakan Pemerintah Dari Filosofi Ke Implementasi, Ed.Pertama, Bandung: Pustaka Setia

[5] Lamintang, P.A.F, 1997, Dasar-dasar Hukum Pidana Indonesia; Bandung, PT. Citra Aditya Bakti.

[6] Lilik Mulyadi, 2007, Putusan Hakim dalam Hukum Acara Pidana: Teori, Praktik, Teknik Penyusunan, dan Permasalahannya, Citra Aditya Bakti, Bandung.

[7] Moeljatno. 2005. Asas-asas Hukum Pidana. Jakarta. Rineka Cipta.

[8] Mukti Aro. 2004. Praktek Perkara Perdata pada Pengadilan Agama. Ed. V.Yogyakarta. Pustaka Pelajar.

[9] Neng Djubaidah, Perzinaan, Ed. 1; Jakarta: kencana Prenada Group, 2010.

[10] R. Soesilo, 1996, Kitab Undang-Undang Hukum Pidana (KUHP) serta Komentarkomentarnya Lengkap Pasal Demi Pasal, Politea, Bogor.

[11] Said Agil Husin Al-Munawar, Jakarta, Hukum Islam, Penamadani, 2005

[12] Tri Andrisman, 2009. Hukum Pidana, Asas-Asas dan Dasar Aturan Umum Hukum Pidana Indonesia, Universitas Lampung.

[13] W.J.S. Poerwadarminta, Kamus Umum Bahasa Indonesia, Third Edition, Balai Pustaka, Jakarta, 2005 